\title{
California Teachers Association v. Riles: Textbook Loans to Sectarian Schools
}

In California Teachers Association v. Riles, ${ }^{1}$ the Supreme Court of California held that a state program providing loans of textbooks, without charge, to educational imstitutions with religious affiliations violated article IX, section $8^{2}$ and article XVI, section $5^{3}$ of the California Constitution, which prohibit public assistance for the support of sectarian schools. The court ruled that determining the validity of the loan program required a two-pronged inquiry: whether the program only indirectly benefits parochial schools, and whether the character of the benefit results in the support of a sectarian school. Applying the first prong, the court concluded that the schools more than indirectly benefited from the program because the benefits accruing to both the students and the schools were "imseparable." Under prong two, the court found that the benefit supported sectarian schools by advancing their educational function. In so holding, the court rejected the theory that the aid would be valid if the child were the direct beneficiary, as well as the presumption that secular books would not be used to teach religion-rationales employed by the United States Supreme Court to uphold three similar textbook loan programs under the first amendinent's establishment clause.

Part I of this Note sets forth the facts and decision of the case. Part II discusses the legal background surrounding Riles. Finally, Part III analyzes the court's opinion. This Note argues that the court did not properly construe the California Constitution because it responded to the first amendinent establishment clause rather than to the appropriate state provisions; that a literal construction of the California provisions

1. 29 Cal. 3d 794, 632 P.2d 953, 176 Cal. Rptr. 300 (1981).

2. Id. at 813,632 P.2d at 964,176 Cal. Rptr. at 311 . CAL. CoNST. art. IX, $\& 8$ states: "No public money shall ever be appropriated for the support of any sectarian or denominational school, or any school not under the exclusive control of the officers of the public schools . . ."

3. 29 Cal. 3d at 813,632 P.2d at 964, 176 Cal. Rptr. at 311. CAL. Const. art. XVI, § 5 states:

Neither the Legislature, nor any county, city and county, township, school district, or other municipal corporation, shall ever make an appropriation, or pay from any public fund whatever, or grant anything to or in aid of any religious sect, cluurch, creed, or sectarian purpose, or help to support or sustain any school, college, university, hospital, or other institution controlled by any religious creed, church, or sectarian denomination whatever; nor shall any grant or donation of personal property or real estate ever be made by the state, or any city, city and county, town, or other municipal corporation for any religious creed, church, or sectarian purpose whatever . . . . 
most accurately reflects the constitution's objectives; and that the Riles two-pronged test does not achieve the objectives of article IX, section 8 or article XVI, section 5 because it allows forms of public assistance which would be prohibited by a literal construction of the constitution.

I

The CAse

\section{A. The Facts}

In 1972, the Califorma Legislature enacted what are now sections $60315^{4}$ and $60246^{5}$ of the Califorma Education Code, establishing a program for lending state-adopted textbooks to nonpublic ${ }^{6}$ school students in grades kindergarten through eight. Under section 60315, pupils enrolled in a nonpublic school could request the loan of text-

4. Originally enacted as Education Code $\S 9505$, CAL. Educ. Code $\S 60315$ (West Supp. 1982) provides:

The Superintendent of Public Instruction shall lend to pupils entitled to attend the public elementary schools of the district, but in attendance at a school other than a public school under the provisions of Section 48222 , the following items adopted by the state board for use in the public elementary schools:

(a) Textbooks and textbook substitutes for. pupil use.

(b) Educational materials for pupil use.

(c) Tests for pupil use.

(d) Instructional materials systems for pupil use.

(e) Instructional materials sets for pupil use.

No charge shall be made to any pupil for the use of such adoptcd materials.

Items shall be loaned pursuant to this section only after, and to the same extent that, items are made available to students in attendance in public elementary schools. However, no cash allotment may be inade to any nonpublic school.

Items shall be loaned for the use of nonpublic elementary school students after the nonpublic school student certifies to the State Superintendent of Public Instruction that such items are desired and will be used in a nonpublic elementary school by the nonpublic elementary school student.

5. Originally enacted as Education Code $\S 9445$, CAL. Educ. Code $§ 60246$ (West Supp. 1982) provides:

The State Controller shall during each fiscal year, commencing with the 1978-79 fiscal year, transfer from the General Fund of the state to the State Instructional Materials Fund, an amount of thirteen dollars and thirty cents (\$13.30) per pupil in average daily attendance in the public and nonpublic elementary schools during the preceding fiscal year, as certified by the Superintendent of Public Instruction, except that this amount shall be adjusted annually in conformance with the Consumer Price Index, all itcms of the Bureau of Labor Statistics of the United States Department of Labor, ineasured for the calendar year next preceding the fiscal year to which it applies. For purposes of this section, average daily attendance in the nonpublic scliools shall be the enrollment reported pursuant to Section 33190 .

6. CAL. EDUC. CODE $\S 60026$ (West 1978) defines a "nonpublic school" as one which satisfies the requirements of Education Code $\S 48222$ (detailing the requirements for a private school whose students are exempt froin attending public school) and is exempt from taxation under $\mathrm{CAL}_{\mathrm{Al}}$. REv. \& TAX. CODE $\$ 214$ (West Supp. 1982) (granting tax exemptions to schools of less than collegiate grade that are "owned and operated by religious, hospital, or charitable funds, foundations or corporations.")

While $\S 60315$ does not on its face confine the loan program to nonprofit, nonpublic scliools, as a resnlt of the three aforementioned statutes, students attending private for-profit schools are not included in the program. See Riles, 29 Cal. 3d at 799, 632 P.2d at 955, 176 Cal. Rptr. at 302. 
books from the list of books approved and adopted by the state board of education for public scliool students. The nonpublic scliool could, on behalf of its individual pupils, place an order ${ }^{7}$ directly with the Department of Education, but officially the loans were given to individual students pursuant to requests from their respective parents. Upon receiving an order, the department ordered textbooks from the state printer or froin other publisliers and shipped tliem directly to each nonpublic school for distribution to the borrowing pupils.

The program was funded througli a transfer of monies froin the state general fund to the state instructional materials fund at the rate of thirteen dollars and thirty cents $(\$ 13.30)$ per pupil in average daily attendance in the public and nonpublic elementary schools during the preceedimg fiscal year. ${ }^{8}$ By 1977 , the cost of the program to the state was approximately two million dollars. ${ }^{9}$

Of the schools participating in the loan program in 1975, 87 percent were religious schools, witl the Catlolic churcli operating 72 percent of these religious institutions. ${ }^{10}$ While these Catliolic schools offer instruction $\mathrm{m}$ secular subjects, they also teacli the tenets of their faith. Some of the schools give enrollment preference to Catholic pupils, and most require students to receive religious instruction, attend religious services during the day, and participate in prayers and religious ceremomies.

The California Teaclers Association ${ }^{11}$ and others challenged sections 60315 and 60246 of the Education Code on the grounds that the statutes violated the establishment clause of the first amendment to the United States Constitution ${ }^{12}$ as well as article IX, section 8 and article XVI, section 5 of the California Constitution. Plaintiffs filed two separate actions: the first sought a declaration that section 60315 was unconstitutional and an injunction prohibiting the superintendent of public instruction, the state board of education, and the state controller from complying with the provision; the second action alleged that the board administered the program in an unconstitutional manner and also sought declaratory and injunctive relief.

7. The order could be for state-adopted textbooks or workbooks or for nonadopted textbooks and workbooks pursuant to CAL. EDuc. CoDE $§ 60200$ (c) (West Supp. 1982). Teachers' editions of textbooks, teachers' manuals, and other directive materials for teachers were excluded from the loan program.

8. See supra note 5 for full text of $\$ 60246$.

9. 29 Cal. 3 d at 799, 632 P.2d at 955, 176 Cal. Rptr. at 302.

10. These figures were cited by the Riles court as having been presented in evidence in the first case. Id.

11. The California Teachers Association is a union representing approximately $197,000 \mathrm{Cal}-$ ifornia public school teachers.

12. U.S. CoNST. amend. I states: "Congress shall make no law respecting an establishment of rehigion, or prohibiting the free exercise thereof . . .." 
The trial court ruled that both the statutes and the administration of the program were constitutional. ${ }^{13}$ The court of appeal affirmed on both counts, holding that the benefits accruing to the nonpublic schools were both indirect and imcidental. It therefore concluded that, under the United States Constitution, such indirect and incidental benefits to rehigious schools are permissible as long as the direct beneficiaries of the loan program were individual pupils and their parents. The court also held that the loan program did not violate the California Constitution because it involved neither official state participation in activity having the direct, immediate, and substantial effect of promoting rehgion, nor the expenditure of public noney for the direct benefit of any sectarian school. ${ }^{14}$

\section{B. The Opinion}

The supreme court reversed, concluding that section 60315 was unconstitutional because it violated both pertinent provisions of the California Constitution. The court held that im assessing the validity of the loan program it is necessary to consider two questions: whether the aid only indirectly benefits the school, and whether the character of the benefit is such that the aid furthers the educational function of the school. In applying prong one, Justice Mosk, writing for the majority, rejected the "child benefit" test used by the United States Suprenie Court to uphold similar textbook loan programs in three prior instances. ${ }^{15}$ Under this theory, if the financial benefit provided by the program accrued to the children and their parents rather than to the schools, if no funds or books were furnished to the school, and if ownership of the books remained "at least technically" in the state, then any indirect benefits to the school did not advance the school's religious mission. Justice Mosk declared that "it is an undeniable fact that books are a critical element in enabling the school to carry out its essential mission to teach the students", ${ }^{16}$ thus the textbook loan progran benefits both the school and the child. Such benefits could not be characterized as remote to one party and direct to the other because the benefits are inseparable.

Applying the second prong, the court held that the loan program violated the California Constitution because the loan of textbooks,

13. 29 Cal. 3d at 798-99, 632 P.2d at 955,176 Cal. Rptr. at 302.

14. See California Teachers Ass'n v. Riles, 167 Cal. Rptr. 676 (2d Dist. 1980), officially depublished pursuant to CAL. CT. R. 976(d) (West 1982).

15. $29 \mathrm{Cal}$. 3d at 807-12, 632 P.2d at 961-64, $176 \mathrm{Cal}$. Rptr. at 308-11 (citing Wolman v. Walter, 43 U.S. 229 (1977); Meek v. Pittenger, 421 U.S. 349 (1975); Board of Educ. v. Allen, 392 U.S. $236(1968))$.

16. 29 Cal. 3d at 810,632 P.2d at 963,176 Cal. Rptr. at 310 . 
which have doctrinal content, ${ }^{17}$ resulted in support for the educational function of the school. ${ }^{18}$ In so concluding, the court further rejected "the [presumption of neutrahity] rationale . . . that a textbook loan prograin may be justified on the ground that it should not be assumed that the parochial schools in which the books are used will einploy the secular texts to teach rehigion." 19 Instead, the court found that the secular and sectarian functions of the school are so inextricably intertwined that any aid to the educational function of the school automatically benefits its rehigious mission.

\section{II \\ LEGAL BACKGROUND \\ A. The California Constitution}

Riles raises the issue of whether a program by which textbooks are loaned at public expense to educational institutions with rehgious affiliations is constitutional in hight of article IX, section $8^{20}$ and article XVI, section $5^{21}$ of the California Constitution. Although no California cases have decided the specific issue of textbook loans to religious schools, two pre-Riles decisions are of significance because they liave addressed the issue of aid to parochial schools under the California Constitution.

In the first case, Bowker v. Baker, ${ }^{22}$ the court of appeal ruled that legislation authorizing the transportation of parochial school pupils in buses owned and operated by a public school district did not violate what are now article IX, section 8 and article XVI, section $5^{23}$ of the California Constitution. Bowker held that where the inain purpose of an enactment is lawful, the fact that an incidental benefit not permitted by law accrues to some person or organization will not alone defeat the legislation. ${ }^{24}$ As a result, the court concluded that the challenged busing program fell under the state's broad police powers to promote the educational welfare and safety of its citizens and that the direct benefit of the legislation flowed to the children, while only an indirect benefit went to their private parochial school. ${ }^{25}$

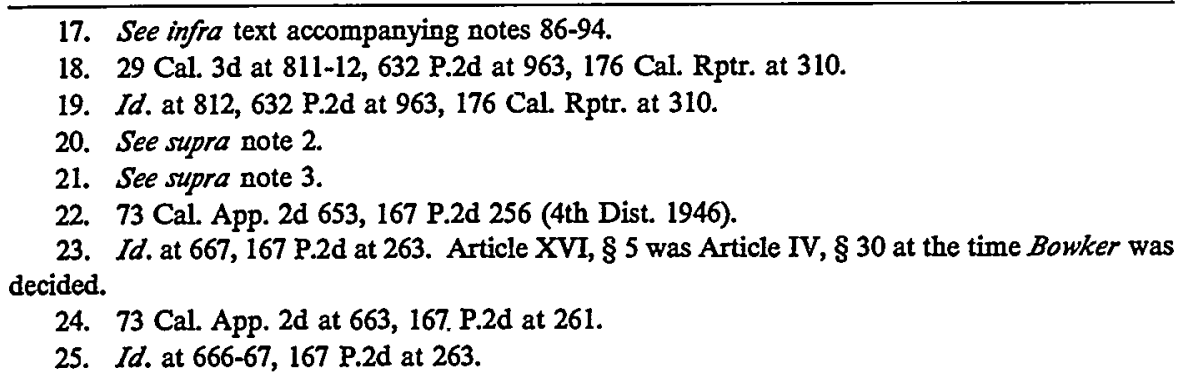


In California Educational Facilities Authority v. Priest, ${ }^{26}$ the California Supreme Court upheld a statute creating a public agency through which private colleges could obtain financing for educational facilities at a lower rate of interest than would be available through conventional financing. Such assistance was valid under article IX, section 8 because it did not require the appropriation of public money, and any indirect or incidental benefits accruing to the schools would not violate this provision. ${ }^{27}$ In addition, the court interpreted article XVI, section $5^{28}$ to forbid "any official involvement, whatever its form, which has the direct, immediate, and substantial effect of promoting rehgious purposes," 29 and therefore to allow sectarian schools to receive indirect, reinote, and incidental benefits from a statute with a secular primary purpose. ${ }^{30}$ Although the court found in this provision a broader prohibition than that of article IX, section 8 , it nevertheless ruled that the benefit resulting from low cost borrowing would only be incidental to the primary public purpose of promoting education by improving and maimtaining educational facilities. ${ }^{31}$

\section{B. The Establishment Clause}

Although Riles was ultimately decided under the California Constitution, the Riles court's analysis and holding are tightly intertwined with the rationales and results of federal cases adjudicating the validity of textbook loan prograins and of comparable forms of aid under the establishment clause of the first ainendinent to the federal Constitution.

To be valid under the establishment clause, a prograin giving public assistance to parochial schools must have a secular legislative purpose, it inust not advance or inhibit religion, and it must not foster an excessive entanglement between government and religion. ${ }^{32}$ To assess the degree of entangleinent, the court inust consider the character and purpose of the institution benefited, the nature of the aid, and the resulting relationship between government and religious authorities. ${ }^{33}$ Additionally, a prograin might be invalidated if a court views it as

26. 12 Cal. 3d 593, 526 P.2d 513, 116 Cal. Rptr. 361 (1974).

27. Id. at 603,526 P.2d at 520, 116 Cal. Rptr. at 368 .

28. At the time Priest was decided, Article XVI, § 5 was Article XIII, $\$ 24$.

29. 12 Cal. 3d at $605-06$ \& n.12, 526 P.2d $521 \&$ n.12, 116 Cal. Rptr. at $369 \&$ n.12.

30. Id. at 605,526 P.2d at 521,116 Cal. Rptr. at 369.

31. Id. at 606, 526 P.2d at 521-22, 116 Cal. Rptr. at 369-70. Contributing to such a determination were these facts: the benefits of the act were granted to sectarian and nonsectarian collcges on an equal basis; the aid for religious projects was strictly prohibited, see id. at 596, 526 P.2d at $515,116 \mathrm{Cal}$. Rptr. at 363; and no financial burden was imposed on the statc. $1 d$. at 606,526 P.2d at 521, 116 Cal. Rptr. at 369.

32. See Lemon v. Kurtzman, 403 U.S. 602, 612-13 (1971).

33. Id. at 615 . 
causing an undue amount of political division along religious lines. ${ }^{34}$

These tests have been developed over a number of years in several inajor cases. In Board of Education v. Allen, ${ }^{35}$ the seminal case on the subject of textbook loans, the United States Supreme Court applied the first two tests, ${ }^{36}$ legislative purpose and primary effect, and uplreld the validity of a loan program similar to the one in Riles. In Allen, the Court reviewed a New York statute requiring local scliool boards to purchase textbooks and lend them witliout charge "to all children residimg in [their] district[s] who [were] enrolled in grades seven to twelve of a public or private school whicl complie[d] witls the compulsory education law." for use in any public, elementary or secondary schools of the state or ... approved by any boards of education" and required as texts for a seinester or more im a particular class in the school the borrower legally attended. ${ }^{38}$ The statute made the textbooks available at the request of the individual student, retained at least technical ownership in the state, and did not ask the student whicl school lie or slie attended. ${ }^{39}$

The Court first held that the express purpose of the New York statute was to increase educational opportunities available to the young. ${ }^{40}$ It then utilized the "child benefit" rationale ${ }^{41}$ to determine that the effects of the statute were not contrary to its stated purpose:

34. See id. at 622-23. Lemon stated that "[a] broader base of entanglement of yet a different cliaracter is presented by the divisive political potential of these state programs." Id. at 622 . The Court, however, did not clearly indicate the weight that the political divisiveness factor should carry, and commentators disagree as to what the Court intended. One commentator asserts that Lemon "was not clear as to whether the political divisiveness factor was merely the reason for strict application of the purpose-effect-entanglement test, a brancli of the entanglement test, or a fourth test." J. NowaK, R. RoTUNDA, \& J. Young, HANDBOOK ON CONSTITUTIONAL LAW 855 (1978) [lieremafter cited as NowAK].

On the other hand, a student commentator argues that the potential for sucl divisiveness does not necessitate invalidation of a statute; rather, that factor's presence should be treated as a "warning signal" of possible unconstitutionality. Note, Wolman v. Walter and the Continuing Debate over State Aid to Parochial Schools, 63 Iowa L. REV. 543, 547 (1977). This latter interpretation of the Court's intention appears to be correct on its face because it is based upon the Court's ruling in Committee for Pub. Educ. v. Nyquist, 413 U.S. 756, 797-98 (1973). In Nyquist, the Court leld that "while the prospect of sucl divisiveness may not alone warrant the mvalidation of state laws that otherwise survive the careful scrutiny required by the decision of this Court, it is certainly a "warnmg signal' not to be ignored." If the word "may" actually means "does," then the Iowa commentator would be entirely correct; however, if it actually means "may," thus leaving open the possibility that political divisiveness by itself could invalidate a statute, then NowaK has a point well taken.

35. 392 U.S. 236 (1968).

36. Based upon previous cases, the two-part test was formally established in Abington School Dist. v. Schempp, 374 U.S. 203, 222 (1963).

37. 392 U.S. at 239.

38. Id.

39. Id. at $241,243$.

40. Id. at 243.

41. See supra text accoinpanying notes 15-16. 
the books were furnished to the children, not to their parochial schools, and any resulting financial benefit accrued to children and their parents, not to the schools. ${ }^{42}$ The Court further based its decision upon the presumption that secular textbooks would not be used to teach religion ${ }^{43}$ and that therefore their purpose would be neutral; the processes of secular and religious training were not so intertwined that secular textbooks furnished to students by the public would in fact be instrumental in the teaching of religion. ${ }^{44}$

Since Allen, llowever, the Court appears to have retreated from the child benefit and presumption of neutrality theories it used in Allen. Furthermore, it has developed a third test-excessive entanglement. ${ }^{4 S}$ This change in the Court's thinking has resulted in its refusal to extend the Allen rationale to programs involving not textbooks, but public aid similar to textbooks. It has continued to uploold textbook loans under Allen only as a matter of stare decisis. ${ }^{46}$

Two cases, Meek v. Pittinger ${ }^{47}$ and Wolman v. Walter, ${ }^{48}$ illustrate the Court's bifurcated approach. In both cases, the Court upheld the validity of textbook loan programs solely on the basis of Allen, ${ }^{49}$ and refused to extend the Allen rationale to loans of funds for instructional materials and equipment. In Meek, the Court held that a Peunsylvania statute authorizing the loan of imstructional materials and equipment ${ }^{50}$ to parochial schools had the primary effect of advancing religion and was therefore unconstitutional. ${ }^{\text {s1 }}$ While Allen was specifically based on the presumption that parochial schools could keep secular and sectarian functions separate, Meek leeld that the secular education and the religious mission of the scloool were "mextricably intertwined," 52 and

42. 392 U.S. at $243-44$.

43. The Court stated: "Nothing in this record supports the proposition that all textbooks, whether they deal with inathematics, physics, foreign languages, history, or literature, are used by the parochial schools to teach religion." Id. at 248.

44. Id.

45. See supra notes $32-33$ and accoinpanying text.

46. 433 U.S. at 252 n.18; NowAK, supra note 34 , at 852,856 .

47. 421 U.S. 349 (1975).

48. 433 U.S. 229 (1977).

49. Wolman, 433 U.S. at 237-38; Meek, 421 U.S. at 359-62.

50. The materials involved were periodicals, plotographs, maps, charts, recordings, and films. 421 U.S. at 355.

51. Id. at 363 .

52. Id. at 366. While the Court utilized in part the "inextricably intertwimed" reasoning to invalidate auxiliary services (including guidance testing and remedial and therapeutic services provided by public school employees at the private schools) in Meek, id. at 367-73, and funds for field trips im Wolman, 433 U.S. at 252-55, it also rehed upon an excessive entanglement test. Meek, 421 U.S. at 372; Wolman, 433 U.S. at 254. For discussion of excessive entanglement test as applied in Wolman, see infra text accompanying note 79.

In Meek, the Court also asserted that the auxiliary services program possessed a serious potential for divisive political conflict because of the recurring nature of appropriations for the pro- 
that loans of imstructional materials would therefore promote religion. When Ohio attempted to avoid Meek by amending its statute so that the aid flowed directly to the children imstead of to the school, the Court in Wolman v. Walter ${ }^{53}$ held the program invalid, thus further undercutting Allen by rejecting its child benefit theory. The Court observed that, despite the technical change in legal bailee, the program in substance was the same as before: the equipment was substantially the same; it would receive the same use by the students; and it could be stored and distributed on the nonpublic school grounds. ${ }^{54}$ Furthermore, while describing the status of the Allen presumption of neutrality in an important footnote to Wolman, the Court acknowledged and tried to resolve the tension between Allen and Wolman. It explained that Allen remamed the law for textbooks only as a matter of stare decisis, but the Court chose to follow its post-Allen cases and not extend the Allen presumption of neutrality to other forms of public aid to parochial schools. 55

\section{ANALYsIS}

In Riles, the Califorma Supreme Court stated that it based its decision upon the Califorma Constitution. ${ }^{56}$ This Section argues that the state's objectives are best achieved by a literal reading of article IX, section 8 and article XVI, section 5. By not imterpreting thein literally, the court did not properly construe those provisions; it responded to first amendment establishnient clause problems rather than Califorma constitutional concerns. The court's two-pronged test would permit

gram. This quality of the appropriation process, said the Court, "guarantees annual reconsideration of the statute and the prospect of repeated confrontation between proponents and opponents of the auxiliary services program. The Act thus provides successive opportunities for political fragmentation and division aloug religious lines, one of the principal evils against which the Establishment Clause was intended to protect." 421 U.S. at 372. This "political divisiveness" factor may constitute a fourth test the Court is using to assess the validity of public aid to sectarian schools. See supra note 34. The introduction of these two additional factors, excessive entanglement and pohtical divisiveness, has made it entirely unclear which factors and rationales the Supreine Court will consider most crucial in deciding whether a particular form of public assistance to sectarian schools is constitutional.

53. -433 U.S. at 250.

54. Id.

55. Footnote 18 reads in part:

"Board of Education v. Allen has remamed law, and we now follow as a inatter of stare decisis the principle that restriction of textbooks to those provided the public schools is sufficient to ensure that the books will not be used for rehgious purposes. . . . It has been argued that the Court should exteud Allen to cover all items similar to textbooks. When faced, however, with a clioice between extension of the unique presumption created in Allen and continued adherence to the principles announced in our subsequent cases, we choose the latter course." Id. at 252 n. 18 .

56. 29 Cal. 3d at 797-98, 813, 632 P.2d at 954, 964, 176 Cal. Rptr. at 301, 311. 
forms of public aid that would be prohibited by a literal construction of the provisions - a result contrary to the objectives of those provisions.

\section{A. Improper Construction of California Constitutional Provisions}

Unlike the establishment clause of the first amendment, the pertinent California constitutional provisions are explicit about the issues to be addressed in determining the constitutionality of state aid to parochial schools. That there is no hidden meaning is strongly supported by the intent and actions of the framers of the California Constitution. At the 1879 Constitutional Convention, the delegates approved article IX, section 8 to assure that public funds would be used to support only the public school system that they were creatimg in article IX of the constitution. ${ }^{57}$ In fact, the language was so clear that the clause was approved without significant debate, and its wording lias remaimed unchanged since its proposal at the convention and its adoption by the people of California. ${ }^{58}$ Thus, from the beginning, the constitutional language prohibited state monetary support not only of any sectarian school but also of any school not under the exclusive control of officers of the public schools. ${ }^{59}$

If article IX, section 8 leaves any doubt as to whether the state can give aid to parochial schools, article XVI, section 5 clearly dispels it. ${ }^{60}$ The convention debates imdicate that that provision "was intended to insure the separation of church and state and to guarantee that the power, authority, and financial resources of the government shall never be devoted to the advanceinent of religious or sectarian purposes." 61 Such intent is plainly reflected in the wording of article XVI, section $5,{ }^{62}$ which constitutes the "definitive statement of the principle of government impartiality in the field of religion." 63 Not only is the legislature or any governmental entity prohibited from ever making an appropriation, but it nay never grant anything which aids any religious

57. Board of Trustees of Leland Stanford Junior Univ. v. Cory, 79 Cal. App. 3d 661, 665, 145 Cal. Rptr. 136, 138 (3d Dist. 1978). The legislature was given the power to establish a public school system by CAL. CoNST. art. IX, $\S 1$, which states that "[a] general diffusion of knowledge and intelligence being essential to the preservation of the rights and liberties of the people, the Legislature shall encourage by all suitable ineans the promotion of intellectual, scientific, moral and agricultural improvement."

58. 79 Cal. App. 3d at 665,145 Cal. Rptr. at 138.

59. Id. In another context, one delegate expressed concern about an "opposition system of schools arising against the common schools of the State." Id.

60. See 29 Cal. 3d at 797, 632 P.2d at 954, 176 Cal. Rptr. at 301.

61. Priest, 12 Cal. 3d at 604, 526 P.2d at 520-21, 116 Cal. Rptr. at 368-69 (citing Gordon v. Board of Educ., 78 Cal. App. 2d 464, 472-73, 178 P.2d 488, 493 (2d Dist. 1947)).

62. See supra note 3.

63. Priest, 12 Cal. 3d at 604, 526 P.2d at 520, 116 Cal. Rptr. at 368 (citing 37 Op. Att'y Gen. 105, 107 (1961)). 


\section{purpose or school. ${ }^{64}$}

By the terms of both constitutional provisions, then, the relevant issues are whether there has been a public appropriation or a grant of "anything,"65 whether the appropriation or grant is in aid of any religious sect, church, creed, or purpose or helps to support or sustain any school, college, or university controlled by any religious creed, church, or denomination; ${ }^{66}$ and whether the school receiving such aid is under the exclusive control of the officers of the public schools. ${ }^{67}$

The court in Riles, however, did not address these issues. Instead, it read prior California case law as establishing a "child benefit" construction $^{68}$ of article IX, section 8 and article XVI, section 5 and then responded to that construction. Rather than developing its twopronged test entirely in response to deficiencies in the California case law construing the state constitution, the court responded primarily to the problems and "logically indefensible" results of the cases interpreting the establishment clause of the United States Constitution. ${ }^{69}$ Tluus,

64. See CAL. Const. art. XVI, $\S 5$.

65. See id; id. art. IX, §8.

66. Id.

67. See id. art. IX, $\S 8$. That a literal construction is most appropriate is supported by other state court decisions involving provisions similar to the ones under consideration in Riles. For example, the Nebraska Constitution provided:

[n]either the state Legislature nor any county, city or other public corporation, slall ever make any appropriation from any public fund, or grant any public land in aid of any sectarian or denominational school or college, or any educational institution which is not exclusively ouned and controlled by the state or a governmental subdivision thereof.

Gaffney v. State Dep’t of Educ., 192 Neb. 358, 361, 220 N.W.2d 550, 553 (1974) (empliasis supplied by court) (quoting NeB. CoNsT. art. VII; § 11).

In holding a Riles-type textbook loan program invalid, the Gaffney court recognized that the proper issues were appareut on the face of the constitution:

[T]o state the constitutional provision is to answer our question. By its terms the provisions [of the statute] furnish aid (in the form of textbooks) to private sectarian schools. By its tems the cost is paid by a public appropriation of tax funds. By its terms textbooks must be used and are given in aid of students in educational institutions which are not exclusively owned and controlled by the state or a governmental subdivision thereof.

Id. at $361-62,220$ N.W.2d at 553.

68. Specifically, Bowker enployed the child benefit theory, and Priest espoused the concoinitant principle "that an indirect, remote, or incidental benefit to a religious school does not violate the provisions of the California Constitution." 29 Cal. 3d at 807, 632 P.2d at 960, 176 Cal. Rptr. at 307.

69. In Gaffney v. State Dep't of Educ., 192 Neb. 358, 220 N.W.2d 550 (1974), the Nebraska court rejected this approach:

The question, . . . here presented, is fundamentally different than the one presented by state action involving an examination of the standards set up by the United States Supreme Court under the Establishment Clause of the First Amendment. It is true the question under the Constitution of Nebraska and the Constitution of the United States both relate to the overall principle of separation of church and state. But, by its terms, the Constitution of Nebraska does not permit of an examination of secular or sectarian purposes, a determination of primary or incidental benefit, or a balancing of the issues involved in state-church entanglement and political divisiveness. There is no ambiguity in our constitutional provision. . . . The standards . . . are whether there is a public appropriation, whether the grant is in aid of any sectarian or denominational school or 
its test is not based upon proper considerations.

The court likely intended the first prong of its test to be a general response to the child benefit theory and, as a result, to the Bowker child benefit construction of the California Constitution. ${ }^{70} \mathrm{~A}$ child benefit analysis would necessitate holding the textbook loan prograin valid because the child receives the direct benefit of the aid, while the school receives ouly indirect and incidental benefits. The first prong of the Riles test refutes this rationale because it rests on the notion that the benefits to the children and school cannot be separated; it does not characterize the aid according to which party benefits inore. ${ }^{71}$ No matter who actually receives the books, both the school and the child benefit, and the benefit to the sectarian school is more than indirect. ${ }^{72}$

Although this part of the Riles test can thus be tied to cases construing the state constitution, the educational function prong, which is the real heart of the Riles test, ${ }^{73}$ has no basis in California precedent. Rather, it is a reaction to the United States Supreme Court's presumption that secular books would not be used to teach religion. ${ }^{74}$ This second prong of the Riles test is based on the contrary rationale that any state aid to the school's educational function imevitably supports its rehigious role because secular and rehgious functions are mextricably intertwined. ${ }^{75}$ However, the neutrality presumption has never been

college, and, perhaps, more importantly, . . that any educational institution which receives such aid must be exclusively owned and controlled by the state or a governmental subdivision thereof.

Id. at 362, 220 N.W.2d at 553. See also Epeldi v. Engelking, 94 Idaho 390, 488 P.2d 860 (1971); Dickman v. School Dist. No. 62C, 232 Or. 238, 366 P.2d 533 (1961); Almond v. Day, 197 Va. 419, 89 S.E.2d 851 (1955).

70. Although prong one is a direct response to the child benefit concept, the court oddly does not refer to Bowker in its critique of that theory but only to Board of Education v. Allen-a United States Supreme Court cases. This makes sense; the court wanted to respond directly to a textbook aid case decided under the child benefit theory, and Allen is such a case, where Bowker is not. However, the court does not discuss the effect that its holding will have on Bowker except to mention at the end of the opinion that it need not consider whether . . Bowker [was] correctly decided. Bowker, unlike the present case did not involve assistance to the educational function of parochial schools in the sense that textbooks aid that objective. Moreover, Bowker . . . reasoned that bus transportation is analogous to the provision of generalized governmental services such as police and fire protection, which are grantcd in common with others, a rationale which is inapplicable to the textbook loan program.

$29 \mathrm{Cal} .3 \mathrm{~d}$ at $813 \mathrm{n} .16,632 \mathrm{P} .2 \mathrm{~d}$ at $964 \mathrm{n} .16,176 \mathrm{Cal}$. Rptr. at $311 \mathrm{n} .16$. Such a statement attempts to rationalize Bowker under the Riles test (notably prong two), but there is still no nention of the former case in relation to the court's formulation of prong one, which is the Riles test's only connection with California case law.

71. $29 \mathrm{Cal}$. 3d at 810, $632 \mathrm{P.2d}$ at 962-63, $176 \mathrm{Cal}$. Rptr. at 309-10.

72. Id.

73. See infra text accompanying notes 82-85.

74. This presumption was first established in Allen and was followed in both Meek and Wolman -all of which involved state aid in the form of textbook loan programs. See supra text accompanying notes $43-44,50-52$.

75. This reasoning follows the rationale employed by the United States Suprene Court in 
used in state constitutional law cases, nor is it a necessary corollary to the child benefit theory. Thus, prong two is designed to remedy a problem withm the federal establishment clause, not California, law. ${ }^{76}$

Another reason for developing the two-pronged test is the court's perception that child benefit analysis leads to "Iogically indefensible" results. ${ }^{77}$ If these inconsistent results were inherent in the child benefit rationale, then it could be said that the court developed its test in response to California law and anticipated future problems witl it since Bowker established child benefit as a part of California constitutional law. However, the imconsistent results are not a function of somethmg wrong with the child benefit theory itself. Rather, they are the results of the Supreme Court reversing its approach to establishment clause cases generally while refusing to overturn the textbook rulings. Since

Meek, 421 U.S. 349 (1975), which invalidated state loans of instructional material and equipment.

There, the Court stated:

The very purpose of many [sectarian] schools is to provide an integrated secular and rehigious education; the teaching process is, to a large extent, devoted to the inculcation of religious values and belief. . . . Substantial aid to the educational function of such schools, accordingly, necessarily results in aid to the sectarian school enterprise as a whole. "[T]he secular education those schools provide goes hand in hand with the religious mission that is the only reason for the schools' existence. Within the institution, the two are inextricably intertwined."

Id. at 366 (quoting Lemon v. Kurtzman, 403 U.S. 602, 654 (1971) (Brennan, J., concurring)).

76. That prong two of Riles evolved from the United States Supreme Court's construction of the establishment clause is further supported by the dichotomy which the Court has established since Allen between educational aid and aid for services that can be classified as health or welfare services. Note, supra note 34, at 557. Although the Riles court does not discuss the establishment clause decisions in this hight, prong two looks surprisingly like the test Justice Marshall, dissenting in Wolman, proposed-a test based on this dichotomy. Marshall would hold that the line between acceptable and unacceptable forms of aid should be drawn "between general welfare programs that serve children in sectarian schools because the schools happen to be a converient place to reach the programs' target population and programs of educational assistance." Wolman, 433 U.S. at 259 (Marshall, J., dissenting). Marshall argued that such welfare programs "do not provide '[s]ubstantial aid to the educational function" " of the school, id. (quoting Meek v. Pittenger, 421 U.S. at 366), as do programs of educational assistance, "and therefore do not provide . . . assistance to the rehigious mission of sectarian schools." Id. at 259-60. Compare Riles, 29 Cal. 3d at 811-12, 632 P.2d at 963, 176 Cal. Rptr. at 310 (formulation of prong two) with Wolman, 433 U.S. at 259-60 (Marshall, J., dissenting) (formulation of Marshall's establishınent clause test).

77. $29 \mathrm{Cal} .3 \mathrm{~d}$ at 809,632 P.2d at $962,176 \mathrm{Cal}$. Rptr. at 309. The "logically indefensible" results the court refers to are the inconsistencies among the Allen, Meek and Wolman decisions. Id. at 807-09, 632 P.2d at 960-62, $176 \mathrm{Cal}$. Rptr. at 307-09. For further treatunent of these cases and their inconsistencies, see supra notes 35-55 and accompanying text.

In stating that child benefit analysis leads to "logically indefensible" resnlts, the court is unclear as to whether it is referring only to the child benefit theory or to the entire Allen rationalechild benefit and the presumption of neutrality. In the preceding paragraph, the court refers to the neutrality presumption, so its subsequent reference to child benefit may be intended to include the presumption-a techrically incorrect use of the term "child benefit." Regardless of what the court meant, however, the same argument applies: the change in theories generally, not any particular theory, has caused the "logically indefensible" results. In fact, if the court is including the presumption in the child benefit theory here, the argument that the Riles test is a response to establishment clause concerns is even stronger, becanse the presumption of neutrality has never been a part of California law regarding the constitutionality of public aid to parochial schools. 
Allen, the Court has reassessed its thinking and has rejected child benefit analysis and the presumption of neutrality, a retreat which has resulted in disallowing the public loan of instructional materials to sectarian schools. ${ }^{78}$

In addition, the Riles court saw it as "logically indefensible" that the Supreme Court in Wolman struck down funds for field trips while upholding loans of textbooks. ${ }^{79}$ While the inconsistent results between other instructional materials and textbooks were the consequence of the Court changing its mind as to how best to determine what the "primary effect" of the aid would be, the inconsistent treatment of field trips and textbooks stemined also from the Court's use of a new, post-Allen establishment clause rationale-the excessive entanglement test. An important reason for striking down funds for field trips was that permitting such funding would allow an excessive entanglement of government and religion by necessitatimg close supervision and surveillance of the student-teacher interaction. This entanglement concept is unique to establishment clause case law and lias not been used by the California courts im construing eitler article IX, section 8 or article XVI, section 5.

Thus, changes in establishment clause theory, not defects in the child benefit theory, have caused the "indefensible" results. Although the Riles court may have believed it was responding to probleins inherent im California's child benefit theory, it was in fact responding to establishment clause problems.

While purportedly construing the California Constitution by responding to perceived problems with the child benefit theory, the court in effect developed a new test for construing the establishment clausea development particularly problematic given the substantial differences between its wording and that of the California constitutional provisions. $^{80}$

78. See Wolman v. Walter, 433 U.S. 229 (1977). The Court has continued to uphold textbook loans, but only in deference to stare decisis. Id. at 252 n.18.

79. $29 \mathrm{Cal} .3 \mathrm{~d}$ at $809,632 \mathrm{P} .2 \mathrm{~d}$ at $962,176 \mathrm{Cal}$. Rptr. at 309.

80. Article I, $\S 4$ of the California Constitution does have language that is almost identical to the federal establishment clause, but the Riles court does not mention its existence. Analyzing the loan program under that provision would have lent inuch greater credibility to the court's discussion of federal case law, because the court may have felt compelled to explain why it was not construing the California establishment clause in the same way that the Supreme Court has construed the federal provision. See Johnson v. Huntington Beach Umion High School Dist., 68 Cal. App. 3d 1, 15, 137 Cal. Rptr. 43, 51 (4th Dist. 1977); Mandel v. Hodges, 54 Cal. App. 3d 596, 616, 127 Cal. Rptr. 244, 257 (1st Dist. 1976). Nevertheless, the court probably chose not to apply article I, $\S 4$ to the textbook loan program on the theory that because article IX, $\S 8$ and article XVI, $\S 5$ contain more explicit language and because they specifically govern school aid cases, they would take precedence over the more general establishment clause. 


\section{B. Failure to Fulfill California Constitutional Objectives}

Despite its doubtful origins, the new test could be defended if it accomplished, however inadvertently, the objectives of the state constitution. This Section argues that the two-pronged test fails to achieve the constitution's objectives because a literal construction of the constitution best reflects the framers' objectives, and the Riles test allows public aid which would not be permitted by a literal construction.

The framers' objectives are clearly reflected in the plain language ${ }^{81}$ of the constitutional provisions. The sections were intended to ensure that public funds would only be used to support the schools created by the state in carrying out its educational responsibility, and to enforce state neutrality in the field of religion by guaranteeing that the power, authority, and financial resources of the government would never be devoted to the advancement of religion.

In determining whether the Riles test achieves these objectives, attention should be focused on the second prong-whether the cliaracter of the benefit results in support of a sectarian school. The first prong of the Riles test-whether the challenged aid only indirectly benefits parochial schools-does not determine the outcoine, because, as the court noted, not all direct aid is prohibited, and not all indirect aid ${ }^{82}$ is valid. Therefore, regardless of whether the aid is direct or indirect, the pivotal question is whether it supports the educational function of a sectarian school. In fact, the court used language ${ }^{83}$ implying that whether direct aid is actually permissible and indirect aid impermissible depends on whether the aid supports the parochial school's educational function. ${ }^{84}$ Thus, given the questionable utility of the first prong, ${ }^{85}$ it is the second

81. See supra notes $2-3$.

82. The court's actual language is "expenditures for the immediate benefit of children." 29 Cal. 3d at 811, 632 P.2d at 963, $176 \mathrm{Cal}$. Rptr. at 310. The court uses "direct" and "immediate" to convey very similar notions. See id. at 806, 632 P.2d at 960, $176 \mathrm{Cal}$. Rptr. at 307. Furthermore, throughout the opinion the court uses the terms "direct benefit to the child" and "indirect benefit to the school" as inutually exclnsive. See, e.g., id. at 805, 807, 632 P.2d at 959, 960, 176 Cal. Rptr. at 306,307 . Hence, immediate aid to the child is direct aid to the child, which is indirect aid to the school.

83. Id. at 811,632 P.2d at $963,176 \mathrm{Cal}$. Rptr. at 310 .

84. This raises the question why the court would set out prong one if indeed it is meaningless to the outcome. However, this question itself assumes that the court intended to make prong one in effect inoperative; perhaps it did not so intend. If the court did intend prong one to be superfluous, it inay have included it in the Riles test because it wanted to refute the child benefit theory and turn attention from the directness or indirectness of a particular type of aid to whether the aid furthered the school's educational function. Creating prong one let it do so without having to iguore or overrule Bowker and Priest.

85. Another reason for questioning the utility of prong one stems from the fact that the court gives no indication as to how far the "inseparability" notion extends. In Riles, benefits to the child from loans of textbooks were held to be inseparable from benefits accruing to the school froin such loans. Conceivably, however, the "inseparability" concept could encompass all forms of aid, because no inatter how indirect the aid might appear, the idea that the benefits are inseparable 
part of the Riles test that must be evaluated in light of the constitutional objectives of article IX, section 8 and article XVI, section 5.

On a superficial theoretical level, one would not expect the Riles test to accomplish the constitution's objectives simply because it asks a question completely different from those required by article IX, section 8 and article XVI, section 5. Prong two looks at whether the aid involves doctrinal content whicl furthers the educational function, while the constitutional provisions ask whether there has been a public appropriation or a grant of "anything," whetler the appropriation or grant is in aid of any religiously affiliated school, and whether the sclrool receiving sucl aid is under the exclusive control of the officers of the public schools. Thus, the Riles test seems inore narrow, so that it would allow more assistance than the constitution would permit.

This difference in wording is insignificant if the Riles test in effect asks the same questions the constitutional provisions do, thus yielding the same results and achieving the same objectives. In order to make such an assessment, it is necessary to determine what the court ineant by the term "educational function of the school." The court concluded that textbooks further the educational function of the school, but that government services, such as police and fire protection, do not. ${ }^{86}$ The critical distinction the court made is that textbooks have doctrinal content while government services do not. Thus, the key is to determine whether a particular forn of aid has doctrinal content. Unfortunately, the court was unclear as to wliat it ineant by "doctrimal content." Nevertheless, lowever doctrinal content is defined, the court's test would allow forins of public aid that would not be permitted under a literal construction of the constitution.

If the court's language is taken literally to mean that the aid itself must liave doctrinal content to be unconstitutional, ${ }^{87}$ then forins of aid like bus rides, funds for buildings, and pencils would be permissible because such items clearly have no doctrinal content of their own. This interpretation of the Riles test would not comport with state constitutional objectives because a state grant of funds for the construction of parochial scliool buildings or for buying pencils is clearly an appropriation of public funds which helps to establish and support or sustain a school systein in opposition to the state public school system. ${ }^{88}$ Similarly, the provision of bus rides, while "assist[ing] . . . students to at-

means that such assistance will always be more than indirect to the school. The ultimate determination of the validity of the aid thus turns on prong two.

86. Id. at 812,632 P.2d at 963,176 Cal. Rptr. at 310 .

87. This would follow from the court's distinction between textbooks and fire and police protection; textbooks themselves have inherent doctrinal content, while fire or pohce protection do not. See id.

88. See Gurney v. Ferguson, 190 Okla. 254, 255, 122 P.2d 1002, 1003-04 (1942). 
tend parochial schools, . . . also aids those schools by bringing to thein those very students for whom the parochial schools were established." 89

Alternatively, aid with doctrinal content could be read more broadly to include anything involved in the student-teacher-textbook interaction that is the the heart of the "teaching-learning process." 90 Under this interpretation, providing funds for pencils would conceivably be invalid assistance because writing is a critical part of the learning process. Although providing bus rides arguably furthers the teaching-learning process by transporting the children to the site of the interaction and learning, the Riles court strongly suggests that bus rides would be allowable because such aid is closely analogous to governmental services and does not aid the educational function "in the sense that textbooks aid that objective." 11

The appropriation of state funds for parochial school buildings poses a paradoxical problein. While such aid is clearly a violation of state neutrality toward religion and is a grant of funds to schools other than those operated by the state, buildings are arguably inore analogous to bus rides than to pencils. Like bus rides, they inerely facilitate the occurrence of the student-teacher-textbook interaction by providing an enclosed site; however, they do not affect the content of that interaction or what is learned in the process, unlike pencils used for writing. Thus, this type of aid could be allowed ${ }^{92}$ under either the literal or the broad interpretation of the Riles test. That the court let stand a decision giving parochial schools a financial break in obtaining loans for maintaining and improving facilities ${ }^{93}$ deinonstrates that such a result

89. Epeldi v. Engelking, 94 Idaho 390, 396, 488 P.2d 860, 866 (1971).

90. The opinion can be interpreted in this manner if the court's allusions to "doctrinal content" and "edncation," 29 Cal. 3d at 812, 632 P.2d at 963, 176 Cal. Rptr. at 310, are read together to refer to that aspect of the child's education which involves doctrinal content. Thus, aid involves doctrinal content if it furthers the actual teacher-student-textbook interaction, which is characterized by the give and take of doctrinal content.

91. Id. at $813 \mathrm{n} .16,632 \mathrm{P} .2 \mathrm{~d}$ at $964 \mathrm{n} .16,176 \mathrm{Cal}$. Rptr. at $311 \mathrm{n} .16$.

92. If such a result were indeed possible, the anomaly which would occur in terms of dollars received by the school would be astounding. The public provision of textbooks involved in Riles would not have saved the schools a great deal of money because, in the absencc of such a loan program, the parents would have been charged a rental fee for the books. $I d$. at 800,632 P.2d at 956, 176 Cal. Rptr. 303. Such public assistance would be deemed by Riles to be unconstitutional, yet the grant of funds for construction of buildings, a benefit to the school of potentially millions of dollars, unight be valid under the same test.

93. Priest, 12 Cal. 3d 593, 526 P.2d 513, 116 Cal. Rptr. 361 (1974). See supra note 26 and accompanying text.

Even inore realistic under Riles than the provision of funds for building classrooms would be the provision of funds for building student dormitories. This latter form of assistance is more consistent with the aid permitted in Priest because the statute in that case prohibited the low interest rates from being used to aid the construction of buildings in which religious activities would take place. Dormitories and dining laalls, on the other liand, were allowed as long as they 
is not altogether unlikely. ${ }^{94}$

It is therefore evident that the Riles test not only appears to be, but in fact is, different from what is contemplated by the California Constitution. Because Riles allows forms of public aid that would be prohibited under a literal reading of the constitution, it fails to achieve the objectives the framers had in mind when they drafted the clear and explicit constitutional provisions prohibiting public support of sectarian schools.

\section{CONCLUSION}

In California Teachers Assocation v. Riles, the California Supreme Court established a new test for determining when public aid to parochial schools is unconstitutional. However, the court developed that test in response to inconsistencies that had developed in cases decided under United States Supreme Court theories for construing the establishment clause of the first amendinent rather than as a result of careful analysis of the meaning and objectives of the substantially different California provisions. Predictably, the court's new test fails to achieve the requisite degree of state neutrality toward and noninvolvement in religion and religious schools because it allows forms of public aid that

were not used in connection with the school's religious instruction or activities. 12 Cal. 3d at 596, 526 P.2d at 515, 116 Cal. Rptr. at 363.

One might nevertheless argue that whether the funds are used for building classrooms or dormitories, the aid still "facilitates the exchange of ideas," by providing either the actual places of learning or the lousing which enables students to attend the school and rcceive the rehigious instruction. If the Riles court had intended its discussion of "educational function" and "doctrinal content" to include any form of aid which "facilitates the exchange of ideas," then such a test would come close to achieving the objectives of the California provisions. For example, bus rides and funding for pencils and buildings all facilitate the exchange of ideas and so would be disallowed.

It is doubtful, lowever, that the court imtended its test to be read so expansively. First, potentially any form of aid to the sclrool can be said to facilitate the exchange of ideas in a tcnuous manner. Furthermore, if the court truly imtended this meaning, it probably would lave established a straightforward test-whether the aid facilitates the exchange of ideas-rather than basing it upon educational function. In fact, it could lave expressly stated its belief that essentially all forms of aid, except those like fire and pohice protection are prohibited. Second, the court let Bowker and Priest stand. Simce the state can thus still provide bus rides and low cost borrowing for construction of buildings - two forms of aid which "facilitate the exchange of ideas" in some manner-the court inust not lave contemplated such a wide reach for the educational function prong of its test.

94. This Priest-type aid would also most likely be deemed impermissible under a literal construction of the constitution because it involves a grant of "anything"-an allocation of the power and authority of the government-to sectarian schools. 
should be prohibited under article IX, section 8 and article XVI, section 5 of the California Constitution.

Gerald A. Kurland*

* B.A., 1980, University of California at Los Angeles; third-year student, Boalt Hall School of Law, University of California, Berkeley. 